\title{
Design of Fuzzy Logic Controller for Charging System with Temperature Condition System in Excavator
}

\author{
Frendit Wijaya \\ Department of Mechanical Engineering \\ Swiss German University \\ Tangerang 15143, Indonesia \\ Email: frenditw@gmail.com
}

\begin{abstract}
Batteries have an important role in the development of energy needs. A good battery performance, will support the device it supports. The amount of battery that can be stored is limited, the battery will experience a charge and discharge cycle. One aspect of battery management is how the temperature in the battery is always controlled. This will place the battery always in the ideal temperature so that it can work optimally. The stages in software design consist of designing a fuzzy logic controller that uses Arduino software. To display the results of reading the system, the Serial Monitor is used in the Arduino software. From the data, the response from the control used will be observed. The system is controlled using the Fuzzy Logic Controller method. In this experiment, the input used is the LM35 temperature sensor. This value will affect the speed of the DC motor which in this experiment is regulated through the determination of the PWM value. There are 3 PWM values, namely 100 for slow motor speed, 200 for medium motor speed and 255 for fast motor speed.
\end{abstract}

\section{INTRODUCTION}

In principle, charging the battery is by flowing the battery with an electric current continuously. Charging is stopped when the battery voltage has reached its maximum voltage (full ocean). Batteries have an important role in the development of energy needs. A good battery performance, will support the device it supports. The amount of battery that can be stored is limited, the battery will experience a charge and discharge cycle. One aspect of battery management is monitoring the state of charge which is the ratio of available energy capacitance to maximum energy capacity. The battery charging device is generally too long and cannot automatically cut off the current when the battery is fully charged. That way the battery must be considered for an estimated time in the filling process so that it does not overcharged. Batteries that are too full or overcharged are very dangerous. The battery when charging raises the temperature and when it is filled too full the temperature will increase resulting in overcharged, where when the condition is left it will result in the temperature increasing too high even the explosion of the battery.

There are several things that cause battery life to decrease, one of which is temperature. Some events can cause the battery to explode because of the heat in the battery. The breakdown unit caused due to the battery damage is very detrimental to both time and material.

Most batteries can last up to five years at normal temperatures, but usually the battery warranty for passenger cars is only two years. The following are some of the causes of battery damage:

1) Electrolyte Level, the electrolyte surface of the battery must be maintained between the upper and lower limits, therefore it must be checked regularly. Electrolyte deficiency will cause the active material to expose and the battery cannot be charged. Lack of battery electrolytes can occur due to a leak in the battery box, rarely doing maintenance, and excessive charging that causes excessive gas. However, excess electrolytes also do not have a good effect. Excess electrolytes will cause corrosion of the battery terminal due to spillage of electrolyte liquid to the terminal when the car is running. Corrosion will inhibit the smooth chemical reaction in the battery.

2) Corrosion, it occurs in terminals, connectors, and metal around the battery, due to liquid electrolyte spilling, or from the results of gas condensation after charging. Corrosion can increase electrical resistance, which can reduce voltage and the charging process becomes ineffective.

3) Vibration, an excessive vibration can cause loosening of the connector, breakage of the box, and endanger the inner components of the battery.

4) Overcharging, the process of charging the battery from the charging system in the vehicle or using separate equipment, which is done excessively will result in gassing. Too much gassing occurs so much active material is lost from the plate. So that the filling process can be disrupted.

5) Excessive electronic equipment, the use of excessive electronic devices on the car can reduce the battery life, especially if the electrical device is used when the engine is off. This can cause the battery to empty, but there is no charging input from the alternator.

6) Temperature, the ambient temperature is a big factor in 


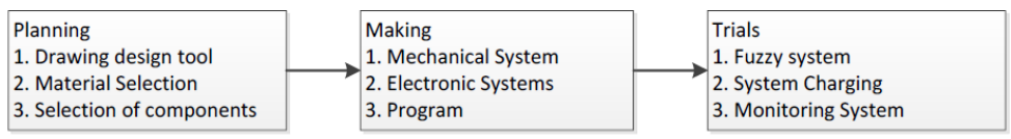

Fig. 1. Scope of Study.

the lifetime of all battery systems. Battery life can be reduced by half if used in extreme temperatures. An increase in temperature can cause damage to the battery components such as corrosion of the positive plate and the battery life cycle becomes shorter.

Temperature also affects the level of battery self-discharge, which is a phenomenon in which battery cells lose the ability to store electrical energy. The lower the level of self-discharge, the longer the battery life, and battery self-discharge will increase with increasing temperature.

Several studies have been conducted related to the research topics that the authors will develop, namely:

1) Applying fuzzy-logic control to maximize efficiency to track and capture sunlight in the photovoltaic (solar cell) energy system for maximum power points. Maximum power point tracker (MPPT) method, based on fuzzy logic controller (FLC), applied to photovoltaic systems. The research method using one converter works as an MPP tracker, while the other regulates the battery charging status and compensates for the decrease in power to provide continuous delivery of energy to the load. The simulation results obtained with this method proved to be better than conventional ones and showed the effectiveness of fuzzy logic proposed by the controller [5].

2) Alvin J. Salkind, Craig Fennie, Pritpal Singh, Terrill Atwater, David E. Reisnerc "Conducted research to predict state-of-charge (SOC) and state-of-health ( $\mathrm{SOH}$ ) from systems on batteries using fuzzy logic, which will predict battery SOC and $\mathrm{SOH}$ without the need to know the history and damage that the battery has experienced before. This method involves the use of fuzzy logic to analyze data obtained by impedance spectroscopic techniques and coulomb calculation techniques. Fuzzy logic provides a powerful tool for modeling complex, nonlinear systems without the need for explicit mathematical models."

3) Using a fuzzy logic system to determine the working condition of the battery based on the voltage and charge status on the battery to overcome the occurrence of problems over usage and damage produced from inbatteryrate estimates of State of Charge (SOC). Fuzzy logic is used to make a decision to disconnect power between the battery and the engine, based on the working conditions of the battery and the amount of power of the vehicle. Simulation results are presented to show the performance of the fuzzy logic energy management system proposed under different driving conditions and charge on the battery. The results show that energy management systems with fuzzy logic based on battery working conditions are effective in ensuring that the engine operates in the area of maximum fuel efficiency while preventing the battery from over-usage [6].

4) Conducting research using the fuzzy logic method to estimate the state of charge with the fuzzy logic method that is by assessing the input and output systems from observations. The researcher analyzed and monitored the battery related to the charge discharge process on the battery so that batteryrate state of charge was obtained to make the battery not damaged quickly. The conclusion of this researcher is the battery monitoring circuit that has been designed to work in accordance with the installed sensors. From the test results it can measure DC voltages up to 27 volts with no error and is able to measure temperature with $0.7 \%$ error. Temperature restrictions are limited according to the standard rules for lead acid batteries, which are -20 yaituC to $50^{\circ} \mathrm{C}$. The design of the battery monitoring system using fuzzy logic has been developed in this study, namely, to obtain an batteryrate SOC value on the monitoring system. To estimate the SOC, 2 membership function inputs are used, namely battery voltage and temperature [2].

5) Conduct research using fuzzy logic control to optimize power control and battery management in hybrid electric vehicles. The overall efficiency of hybrid vehicle batteries can be optimized by identifying the best degree of Hybridization (DOH) and power control strategies. Fuzzy logic is used in the power distribution of hybrid vehicles, where the center and width of the membership function are optimized. Simulation results show that hybrid vehicles that are designed and controlled optimally can provide good battery savings and overall system efficiency [7].

\section{MAterials AND Methods}

Broadly speaking, the stages in this study are divided into three main parts, namely, planning, making tools and testing, research stage diagrams are shown in Figure 1.

In Figure 2, the main material of this tool is the Arduino Uno microcontroller which is the brain of the sensor that will regulate the running of the system within the tool. And of course there are additional components so that the system can run properly such as $12 \mathrm{~V}$ battery, temperature sensor, voltage sensor, current sensor. 


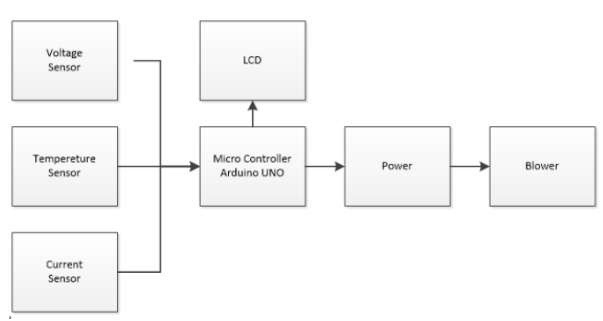

Fig. 2. Schame plan.

A mechanical system device (Fig.3) is a part that includes a battery charging system and a fan and blower for air conditioning on a battery that is experiencing heat due to the charging process.

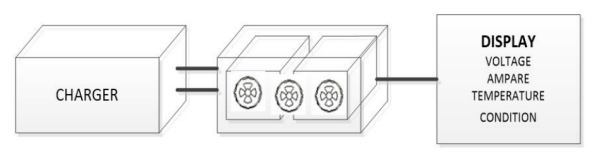

Fig. 3. Design plan.

\section{RESUltS AND DISCUSSION}

The first step is to measure the temperature in the real condition of the battery. this measurement aims to find out which ticks are the most hot from the area and the battery itself.

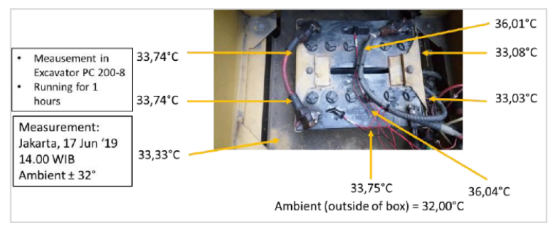

Fig. 4. Measurement temperature battery in excavator.

From all these experiments it can be concluded that the upper battery has higher heat compared to the other side and ambient temperature. This is in line with the theory that there are several main causes, namely overheating and overcharging so that the battery life is shorter. Heat causes the battery liquid to evaporate, damaging the internal structure of the battery. Evaporation causes the upper side of the battery to be hotter than the other parts.

Electrical system design planned in this study uses Arduino Uno and Fuzzy Logic. The design of this system is equipped with several hardware, namely a $1000 \mathrm{rpm}$ DC motor, propeller, LM35 temperature sensor, Arduino Uno, motor driver

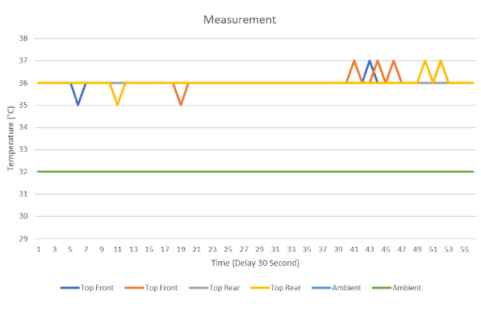

Fig. 5. Measurement in excavator.

circuit and 10 Volt battery. The design of this system is used to adjust the fan rotation which is adjusted to the temperature and distance of an object. The hardware diagram is as follows:

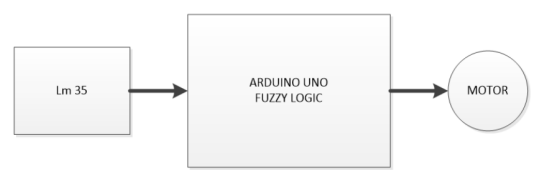

Fig. 6. Schema Fuzzy.

After initializing the variable and reading the sensor, the next step is to design a Fuzzy Logic Controller. The Fuzzy Logic Controller is divided into 3 stages, namely:

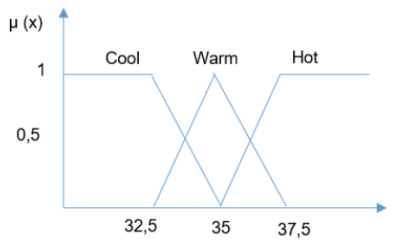

Fig. 7. Temperature Membership Function.

The temperature sensor membership function (LM35) consists of Cold, Warm and Hot. This is shown in Figure 8.

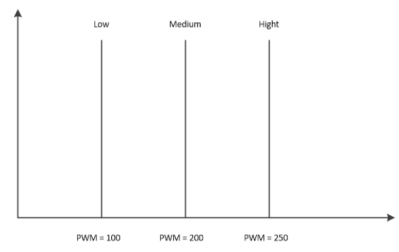

Fig. 8. Motor Speed Membership Function. 


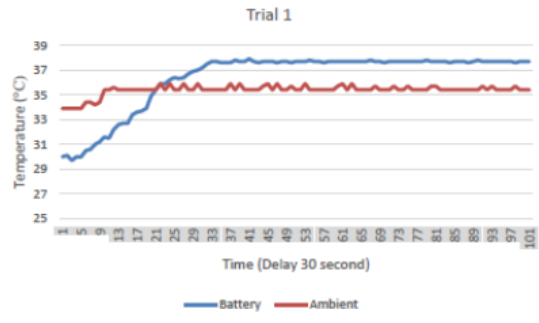

Fig. 9. Trial 1.

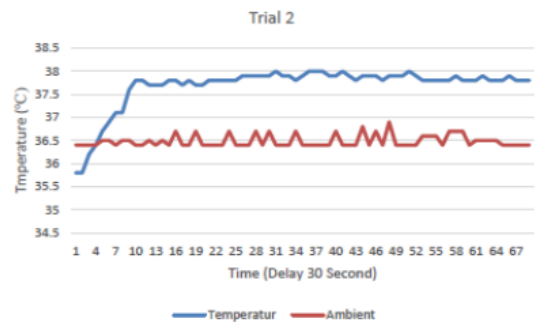

Fig. 10. Trial 2.

\section{CONCLUSIONS}

From this research that has been done, some conclusions can be taken as follows: (a) Temperature in the battery can increase because of the process inside the battery and the closed battery space condition, (b) The temperature can be lowered by removing the hot air inside the battery and blowing the air through the fan, (c) The battery condition will work at the ideal temperature which can make the battery work optimally, and (d) Fuzzy logic is proven to be able to regulate the temperature of the battery so that heat can be controlled.

\section{REFERENCES}

[1] H. Andri, Rancang Bangung System Battery Charging Aoutomatic. M.S Thesis, Teknik Elektro., Universitas Indonesia,Depok. 2014

[2] A. F. Farizy and D. A. Asfani, Desain Sistem Monitoring State of Charge Baterai pada Charging Station Mobil Listrik Berbasis Fuzzy Logic Dengan Mempertimbangkan Temperature. vol. 5, no. 2. 2016

[3] D. Setiawan, Rancang Bangun Sistem Pengisian Baterai Secara Cepat Dan Pemutus Arus Otomatis Dengan Regulator LM338K, M.S. Thesis, Teknik Elektro., Universitas Muhammadiyah, Surakarta. 2017

[4] A. Dukti, Rancang Bangun Alat Monitoring Proses Charging Battery Berbasis Arduino Uno IC Atmega 328,M.S. Thesis, Teknik Mesin., Politeknik Negeri Balikpapan,Balikpapan. 2017

[5] S. Lalouni, D. Rekioua, T. Rekioua, and E. Matagne, Fuzzy logic control of stand-alone photovoltaic system with battery storage, J. Power Sources., vol. 193, pp. 899907. 2009

[6] S. G. Li, S. M. Sharkh, F. C. Walsh, and C. N. Zhang, Energy and Battery Management of a Plug-In Series Hybrid Electric Vehicle Using Fuzzy Logic, IEEE Transactions On Vehicular Technology., vol. 60, no. 8, pp. 35713585. 2011.
[7] C. Y. Li and G. P. Liu, Optimal fuzzy power control and management of fuel cell/battery hybrid vehicles, J. Power Sources, vol. 192, no. 2, pp. 525533. 2009

[8] M. Suresh, B. Viswanath, Ajit Kumar Mohanty, Fuzzy Logic Control and Coordination of Battery Energy Storage System with Standalone Wind Powered DC Micro Grid. 2017

[9] Komatsu, Shop Manual PC 200-8 MO, Komatsu. 2012.

[10] Technical Training Department, Basic Mechanical Course, Electrical System. Komatsu, 2012.Training Aid \& User Text, Komatsu. 2012

[11] Imron, Muhammad, Rancang Bangun Battery Charger Dengan Metode Incremental Conductante Mengggunakan Arm STM32F4, Teknik Elektro Industri, Politeknik Elektronika Negeri Surabaya. 2017.

[12] Novia, Rancang Bangun Alat Monitoring Proses Charging Battery Berbasis Fuzzy Logic, Teknik Mesin, Politeknik Negeri Balikpapan, 2018

[13] Yu-Shan Cheng, Yi-Hua Liu, Holger C. Hesse, Maik Naumann, Cong Nam Truong and Andreas Jossen, A PSO-Optimized Fuzzy Logic ControlBased Charging Method for Individual Household Battery Storage Systems within a Community. 2018.

[14] Leonandi Agustian, Rancang Bangun Sistem Monitoring Kondisi Aki Pada Kendaraan Bermotor, Program Studi Teknik Elektro Jurusan Teknik Elektro Fakultas Teknik Universitas Tanjungpura Pontianak. 2015.

[15] Riasty Purwandari, Makalah Baterai, Jurusan Pendidikan Teknik Kejuruan Progam Studi Pendidikan Teknik Mesin, Fakultas Keguruan Dan Ilmu Pendidikan, Universitas Sebelas Maret Surakarta Pendidikan Teknik Mesin. 2014

[16] Mohamad Faizal.H, Mariza Fitri, Analisis Penyerapan Panas Pada Cover Accu Di Mobil Su, Program Studi Teknik Mesin, Institut Sains dan Teknologi Nasional, Jakarta Selatan, Indonesia. 2016. 